\title{
6 The long walk towards uncertainty
}

\section{The migrant dilemma in times of COVID-19}

\author{
S. Irudaya Rajan, Renjini Rajagopalan, \\ and P. Sivakumar
}

\section{Introduction}

The onslaught of COVID-19 thrust upon humanity two major challenges, that of human health and that of the economy; our migrants are mired in both. It has both pushed the world economic order into chaos and challenged even the mightiest of economies. The initial advent of COVID-19 sowed confusion within systems of governance as countries struggled to deal with its unprecedented threat. In order to control the spread of the infection, countries across the globe, including India, took to strictly limiting movement of the masses. This severe and unprecedented curtailment of mobility through strict lockdown made evident that the first and worst victims of the pandemic are the marginalised, the migrants.

In the context of COVID-19, rural-urban migration has attracted the most attention given that the retreat of migrants from their urban centres has been the most visible aspect of the pandemic. The pandemic has both exposed the magnitude of India's dependency upon internal migrants for low-end jobs and the vulnerabilities they face in spite of such dependency. Additionally, this is going to destabilise India's aspirations in achieving its Sustainable Development Goals (SDGs), as the country will be compelled to address poverty from scratch so as to bridge the inequities that have cropped up as a result of the pandemic. Doing so will also require us to rethink our strategies when it comes to migrant welfare and come up with both short-term measures to alleviate migrant suffering and longterm approaches that are able to address the systemic vulnerabilities and injustices.

The economic and social crisis generated by the COVID-19 pandemic is deeper and more pervasive than any other pandemic that has affected the world since the 1900s, affecting almost every sector and its workers (World 
Bank, 2020b). When it came to migrant workers, the most affected section were unskilled and semiskilled migrants whose day-to-day livelihoods suddenly vanished. With many such migrants inhabiting the informal sector and working on a contractual basis, they faced the prospects of immediate termination of employment much before their formal counterparts. Many sought to go back to their villages, but the absence of transport prevented them from doing so. State governments sought to set up relief camps and shelters to accommodate migrants, but implementation was skewed. Faced with increasing economic distress and the prospect of utter destitution, many were compelled to break government norms on travel and curfew and walk hundreds of kilometres to reach their hometowns. For an unfortunate few, this ended in the tragedy of death.

This chapter briefly summarises the Indian migrant experience during COVID-19. We look at existing and ongoing labour reforms, particularly with respect to labour rights and migrant welfare. In doing so, it looks at existing and ongoing institutional reforms, particularly with respect to social welfare, labour rights, and migrant welfare, and concludes that migrant welfare needs to go beyond stop-gap arrangements towards enacting a comprehensive body of changes aimed at improving their overall circumstances.

\section{Trends and patterns of internal migration}

Migration has a history as old as humanity, and India is no exception to this. India has long been the land of the world's largest voluntary and involuntary migration (Tumbe, 2018). On the basis of geographical movements, internal migration can be classified as rural-rural, rural-urban, urban-rural, and urban-urban, while its purpose can result in migration being time-bound and seasonal, or driven by other permanent or semi-permanent factors. Each of these patterns has been catalysts for India's changing demography and deserves to be studied at depth. But the phenomenon of return migration and the possibility of remigration in the aftermath of the COVID-19 pandemic limit our focus to that of labour migration in the rural-urban context and the vulnerabilities of migrants occupying this space.

There are significant studies on internal labour migration and how it contributes to addressing poverty in low-income countries (Deshingkar, 2006; Rajan and Sumeetha, 2019). The 2030 Agenda for Sustainable Development recognises, for the very first time, the contribution of migration to sustainable development (Migration Data Portal, 2019). Dwindling livelihood opportunities, meagre wages, and limited resources thus provide impetus for rural to urban migration. However, such migrants are often handicapped by the loss of their social and cultural identities, among other things. The absence of critical skills and adequate bargaining power further compels 
them into exploitative environments where they are forced to engage in low-end, low-value, and hazardous work (Aajeevika Bureau, 2014).

However, government response to the phenomenon of internal migration has largely been one of apathy. A World Bank 2018 report highlights this indifference in the very documentation of migrants in India. Multiplicity of data points over years, and overlapping classifications aside, each have their own definitional shortcomings, including the incapability of adequately addressing gender concerns or certain classes of migrants such as circular or short-term migrants (Nayyar and Kim, 2018). Besides this, surveys and other data collection processes only count the respondents who affirm their presence at the time of such an exercise (Rajan et al., 2020). Invariably, it is likely that both our data and understanding of migrants are severely underdocumented (Government of India, 2017).

The 2011 census data indicates that internal migration in India accounts for 37.4 per cent of the total population as compared to 31 per cent in 2001. With the total number of internal migrants in India numbering at 453.6 million in 2011, we also see a 45 per cent increase as compared to 2001. Besides the substantial increase in overall numbers, there is also considerable change in gender dimensions with regard to India's internal migration (Figure 6.1).

The unprecedented growth of million-plus cities and dwindling economic opportunities in rural areas are understood to be key factors of massive migration. According to the 2011 Census, Uttar Pradesh and Bihar are the largest source of inter-state migrants, while Maharashtra and Delhi were seen to be receiving states due to their demographic dividend (Rajan, 2013). That said, much of the migration over the last few decades seems to be intra-district migration (see Figure 6.2).

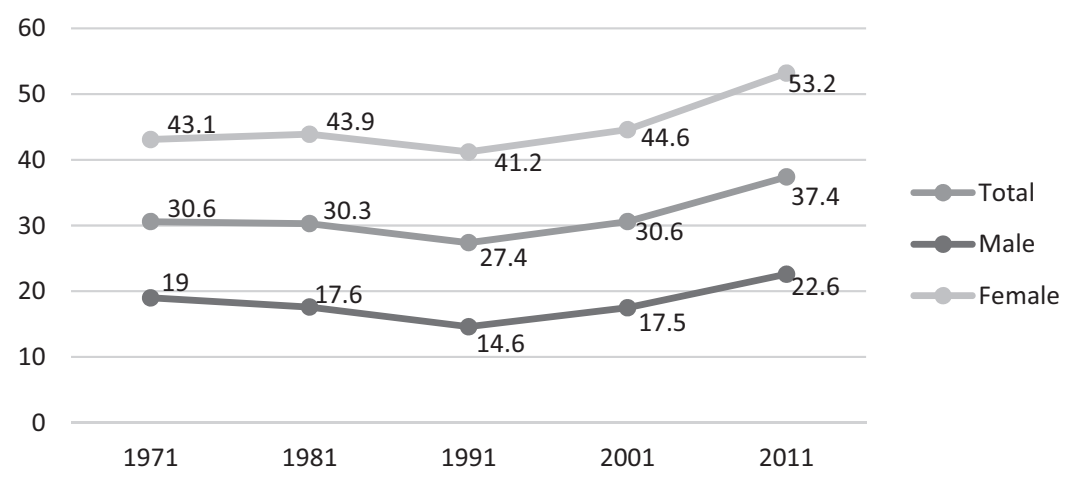

Figure 6.1 Internal migration in India, 1971-2011. Source: Census reports. 

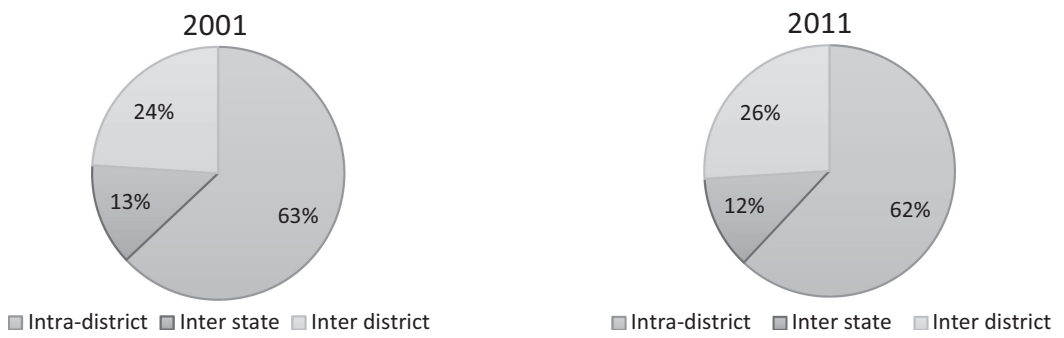

Figure 6.2 Distribution of internal migrants by type of movement. Source: De, 2019.

A 2016 World Bank study on internal migration sheds light on this phenomenon by highlighting how despite internal mobility being a key driver of economic growth across regions, it may remain inhibited in India by the existence of state-level entitlement schemes - primarily, the inability to port social welfare measures for migrants, across state borders (Kone et al., 2017).

\section{Migration, migrants, and the COVID-19 impact}

\section{Socio-economic impact of COVID-19 on migrants}

The reverse migration generated by COVID-19 poses a massive challenge to migration governance. The problems with employment that predated the pandemic continue to remain at play with the added shock to the economy, making re-employment and income generation difficult. While many migrants remain resolute in not wanting to return back to the urban spaces that once housed them, they struggle to assimilate into their rural hometowns in the face of extreme impoverishment as well as suspicion of being COVID carriers (Migrants flee cities, 2020). In turn, officials in such rural hometowns grapple with ways by which the returning masses can be accommodated. Though MGNREGA has been touted as a possible shortterm solution, there is a limit to absorption of labour under it, and migrants will eventually be compelled to squeeze themselves into sectors like agriculture, which is already saturated.

Over 90 per cent of working population in India is currently engaged in the informal economy, with states such as Uttar Pradesh and Bihar accounting for more than 80 per cent of workers in this sector, most of them migrants (Patel, 2020). For instance, Stranded Workers Action Network (SWAN) (2020) survey chronicling the hardships faced by migrant workers 
during the initial weeks following the lockdown saw the largest number of respondents emerge from the states of Bihar ( 25 per cent), Jharkhand (28 per cent), and Uttar Pradesh (13 per cent). Also, of all the Shramik trains transporting migrants operated in May, the highest were for the states of Uttar Pradesh and Bihar (Dastidar, 2020).

Investigations like SWAN (2020) highlight how migrant distress has far exceeded any relief provided. However, the pandemic has only exploited existing vulnerabilities and injustices plaguing migrants, the presence of which has been made apparent to governments well before the advent of the pandemic. Case in point is the 2017 Report by the Working Group on Migration constituted by the Ministry of Urban Housing and Poverty Alleviation, which was tasked to look into ways by which migrant welfare could be uplifted. Their report identified 53 districts (based on Census, 2001) seeing major male inter-state migration, of which 24 belonged to the state of Uttar Pradesh, followed by 20 districts from Bihar (Government of India, 2017). Yet, to-date their recommendations remain pending with the Government of India (Prabhu, 2020; Rajan and Sami, 2020); their delayed implementation will now adversely impact the dignified rehabilitation of India's migrant labour.

\section{COVID-19, migration, and the gender lens}

Migrant women have been on the frontlines of the COVID-19 pandemic, even though the public narrative about migration has been largely masculinised. Gender norms in particular prop up their own barriers when it comes to migration in the form of policy restrictions, discrimination, violence, and exploitation. Despite this, multiple women migrate internally and outside country boundaries for social, educational, and economic concerns. It is estimated that half of over 272 million migrants in 2019 who lived and worked outside their countries of origin were women, of which 66 million were migrants (Anonymous, 2020). This is true for within India too, where the primary cause of internal female migration was seen to have been marriage or associated migration (Rajan and Sivakumar, 2018), but many who did so subsequently also entered the labour force, though surveys have failed to adequately capture this (Prabhu, 2020; Rajan et al., 2020).

Gender norms and societal barriers result in women being excluded from the formal labour market, and even in an informal one, they are found at the bottom of the pyramid, employed in low-paid, insecure, and informal spaces like domestic workers, sanitation workers, and care givers. The ILO estimates the highest percentage of women ( 58.2 per cent) to be employed in the service sector (World Bank, 2020a) and they have been hardest hit by COVID-19 (Sharma, 2020; Sapra, 2020), putting women migrants in a far 
more precarious situation as compared to their male counterparts. Rukmini (2020) estimates that in India alone, within 2 months of lockdown, 4 out of every 10 working women lost their jobs, resulting in over 17 million women being rendered jobless. Despite such sizeable distress, the absence of inclusivity in the labour economy and the general lack of gender sensitive policy-making have rendered the suffering of women migrants invisible (Sapra, 2020).

Paid work aside, all other factors that constrain women in the labour force have also been exaggerated as a result of the pandemic. Women bear a disproportionate amount of the care work globally; UN Women 20152016 (Nandi, 2017) reveals how in India alone, women do 7 times as much unpaid work as men yet are treated as non-workers because they do not engage in work considered 'economically productive'. During COVID-19, the lockdown, coupled with social and gender norms, has forced women to put in greater number of hours into domestic labour, which run counter to social distancing norms thereby increasing their risk of contracting virus (The Week, 2020). They have also been at the receiving end of greater sexual violence as well as domestic abuse, and many report health issues due to their inability to access health, sanitation, and nutritional services due to the disruption and re-routing of, public services to fight the pandemic.

The intersectionality of migration is such that women, who are urbane and educated, and who have overcome social, economic, and gender barriers have fared better in general, and continue to do so regardless of the pandemic. But for those who are economically disenfranchised and those who belong to disadvantaged castes and communities, who form the vast majority of migrant women, the economic downturn coupled with the vagaries of working in the informal sector has rendered them far more vulnerable than they have ever been before. Experts suspect that in the aftermath of the pandemic, problems of debt, loans and mortgage will end up burdening these women, resulting in distress sales of property, child marriage, and even prostitution (Rajan et al., 2020). Unless the gendered aspect of migrant distress is recognised, and sound, inclusive, and gender-responsive policies are quickly enacted, such women will be forced to contend with a far worse exploitative environment in the new economic normal.

\section{Institutional responses and state initiatives tackling the migrant crisis}

Cognisant of the deep economic impact of the COVID-19 lockdown on the economy, the Centre quickly galvanised its resources to introduce a financial stimulus package called the Pradhan Mantri Gareeb Kalyan Yojana, which covered various categories of people from women to informal workers and 
many others (PIB India, 2020). It provided a combination of food support and cash transfers through existing schemes like MGNREGA, PM-KISAN Yojana, Ujjwala, etc., and leveraged institutional mechanisms like PDS and Jan Dhan bank accounts for disbursement. While these measures may have no doubt proved beneficial for those already included within such scheme ecosystems, it nevertheless proved exclusionary to low-income groups not enrolled in the existing schemes and those on the move, a large number of whom happen to be internal migrants. This realisation has resulted in the Centre augmenting these measures by way of a compendium of initiatives under the 'Atmanirbhar Bharat Abhiyaan' or Self-Reliant India initiative. However, as Iyer (2020) reports, its uptake leaves much to be desired. Attempts have also been made to collect migrant data so as to ensure their assimilation back into the workforce. The setting up of an online centralised dashboard - the 'National Migrant Information System' (NMIS) under the National Disaster Management Authority (NDMA) - to track migrant movement across states (Ministry of Home Affairs, 2020), and the proposed data bank dedicated to tribal migrant workers who are returning to their home states under the aegis of the Ministry of Tribal Affairs (Mitra, 2020), are some such efforts.

The pandemic has also forced all states, in particular those now at the receiving end of the return migration, to contend with migrant issues beyond the initial short-term rehabilitation measures of food and shelter. Faced with the possibility of long-term rehabilitation and reintegration of migrants, states have begun to undertake various measures, from collecting data on skilled and unskilled migrants (Rajasthan), to their skills mapping (Uttar Pradesh and Jharkhand), to setting up platforms and authorities to address their specific needs (the Migrant Commission in Uttar Pradesh) to online platforms to enable the skilled migrants to connect to employment opportunities (Madhya Pradesh) (Venugopal and Gaur, 2020; Srivastava, 2020; Sharan, 2020; Yadav, 2020).

That said, some of these states (Uttar Pradesh, Madhya Pradesh, Gujarat, and Rajasthan) have also diluted existing labour norms for a set time period, in an aggressive effort to reclaim economic growth and revitalise the economy, prompting fears that they will end up accommodating migrant workers in an economy devoid of basic legal protections for them (Jha, 2020; Rajan et al., 2020).

\section{The need for social protection systems for migrants}

Srivastava (2013) notes that India's labour market has long been characterised by extreme inequalities that result in the most vulnerable being subjected to high levels of livelihood insecurity, culminating in poverty and 
vulnerability. The Ministry of Statistics and Programme Implementation (2019) Periodic Labour Force Survey found that among regular wage/salaried employees in the non-agriculture sector over 71.1 per cent had no written job contract, 54.2 per cent were ineligible for paid leave, and 49.6 per cent did not qualify for any social security benefit.

Such inequities have become exacerbated as a result of the economic disruptions caused by the COVID-19 (Coronavirus in India, 2020). The World Bank estimates on global poverty looks at impoverishment in the aftermath of COVID-19 across the globe, and offers 'a sobering picture' for India by stating that extreme poverty is likely to remain unchanged, but that the country is expected to see more poor emerging post-COVID (Mahler et al., 2020). Juxtapose this against the latest data on how India has managed to lift approximately 273 million people out of multidimensional poverty over the last decade (UNDP \& the OPHDI, 2020) and one realises that the recent economic shocks delivered to India's economy by the pandemic has the ability to derail any progress achieved over the last ten years. This includes any gains made towards attaining the Sustainable Development Goals, given how migration is a cross-cutting issue, finding relevance under targets and indicators under 11 out of 17 SDGs (Migration Data Portal, 2019).

This is where social protection, namely the ability to access it, gains importance. Enabling strong systems of social protection offers a safety net that protects the poor and the economically vulnerable from deprivation. In times of unprecedented crisis, such as the one brought about by the current COVID-19, they offer a guaranteed safety net so that migrants do not fall back into poverty.

\section{The link between social protection and labour reforms}

India has had a plethora of social safety net programmes since the early 1970s which have ranged from self-employment and wage employment programmes to food and nutrition schemes and health care. However, these programmes have traditionally sought to ameliorate deprivation via promotional measures such as offering social assistance, rather than protective ones that help deal with contingencies like health shocks, death, or disability (Sharma and Arora, 2011). More tellingly, these programmes tend to cover only those belonging to the formal and organised sectors, while an overwhelming majority of India's workforce languish in informal and irregular employment. Nowhere is this more apparent than in the nature of India's labour laws whose applicability is confined only to India's organised sector, while systematically depriving those in the informal sectors - like migrants - of the same protection. 
However, India has not been entirely unaware of the need to protect informal and migrant workers. The Centre has devoted the last couple of years towards creating social security measures such as pensions (the Pradhan Mantri Shram Yogi Maan-dhan) and health insurance specifically catering to their needs, though the uptake has not been overly successful (Mitra, 2020). However, benefits of central government schemes are often tied to concepts of 'domicile', and relayed by state or local governments to those who permanently reside within their borders, thereby becoming inaccessible to inter-state migrants. Some states wilfully exclude migrants by way of domicile-based reservations in jobs, education, and service delivery (Mitra et al., 2020). However, there has been a growing recognition of the gap between how deeply entrenched migrant welfare and protection is to the space they occupy in the labour economy. Certain states like Kerala, home to migrant labour friendly policies from pre-pandemic times, with the Kerala Inter-State Migrant Workers Welfare Scheme, 2010, the Awas scheme, 2017, and the Apna Ghar Hostel Scheme, 2017, stood out for having successfully identified and housed its migrants, and securing them their entitlements during the pandemic (The Week, 2020; Rajan, 2020).

The ongoing attempts of the government to reform India's labour laws and converge them into 4 Labour Codes, in particular the introduction of the Code on Social Security 2019, must also be seen from the lens of migrant welfare. At its simplest, the Bill seeks to enhance the ambit of what constitutes a worker, and for the first time recognises categories of workers such as gig, platform, unorganised workers, freelancers, homebased, and self-employed workers as those deserving of social security measures (Ministry of Labour, 2019). Recent discussions on the Bill by the Parliamentary Standing Committee vetting the same have also made a strong pitch for improving the coverage of Employees' Provident Fund (EPF) and Employees State Insurance Corporation (ESIC) to an estimated 30 lakh migrant workers (Ray, 2020). However, critics have pointed out that efforts to broaden definitions of what constitutes a 'worker' and an 'employer' to ensure greater inclusivity have resulted in definitions that are rather ambiguous, and that the Bill does not clarify if its schemes at all extend to the unorganised sector, thereby prompting fears that migrant households might find themselves doubly excluded by virtue of being migrants (Simran et al., 2019). Therefore, social protection policies must go beyond strengthening labour norms.

\section{Concluding remarks}

The contours of what a comprehensive migrant welfare framework might look like requires a more nuanced look at migrant distress that covers 
various types of internal migrants as well as an in-depth inquiry into intersectional concerns involving various sub-categories of the migrant demographics. That said, certain institutional reforms and policy interventions offer an axis from which to further future reform. An attempt has been made to briefly summarise the definitional discrepancies, suggesting robust credible data collection systems, ensuring portability of social welfare, and enabling political franchise of migrant workers.

Existing research pinpoints discrepancies in data collection regarding internal migrants and the circumstances underlying their migration. From definitional gaps that are unable to adequately capture the nature of migration such as seasonal or cyclic migration to those that ignore the eventual entry of female migrants into the labour force after marriage, there are many such concerns. This highlights a need for consistency and uniformity in the way migration is defined. One way to do this could be to appropriately amend migrant classifications under the Census, and use it to survey migrants across the country. This can later be leveraged by Ministries of Women and Child Development, Social Justice, and/or Minority Affairs to better their dispensation of schemes or benefits to their target audience.

While multiple surveys and research platforms - both government and otherwise - curate migrant data, they do not do so at regular timely intervals, and sample sizes greatly vary. Also, few states have been consistently capturing migrant data, and national estimates vary greatly from state estimates. Kerala once again stands out here since it has had the benefit of numerous data captures, beginning from Centre for Development Studies-Kerala Migration Surveys (Zachariah et al., 1999, 2000; Rajan and Zachariah, 2019), down to several government efforts (Narayana et al., 2013). However, it is imperative that robust, regular, and credible data collection that can be routinely accessed and updated be collected in a centralised manner and in real time.

Many states have begun this enterprise now, and the Centre too has set up the National Migrant Information System to capture migrant data, though the former suffers from geographic limitations, and the latter stops at migrants repatriated back to their home states. Therefore, it is important to integrate these efforts to create a single, national online data repository that is accessible across states, into which states can feed their migrant data regularly. The ground work for such data collection can already be found in legislations like the Inter-state Migrant Workmen (Regulation of Employment and Conditions of Service) Act, 1979 (replaced by the Occupational Safety, Health and Working Conditions Code, 2020) and the Unorganized Workers' Social Security Act, 2008. However, efforts will have to be made to ensure that such a process is inclusive and captures data of those migrants who are not formally or traditionally employed. 
Here, Jharkhand's method of relying on Sakhi Mandals, the state's SHG networks, to help with data capture for skills mapping offers a good example of creatively leveraging other institutional networks to help with such efforts (Bisoee, 2020). Such steps will help governments design better evidence-based welfare measures and dispense social security in a targeted fashion for migrants in the long-term. More importantly, enabling the timely collection of reliable data will also go a long way towards 'facilitating the orderly, safe, regular and responsible migration and mobility of people, including through the implementation of planned and well-managed migration policies', which is a direct target set under Goal 10 of the SDGs.

With many social protections being tied to permanent residences, migrants remain perennially outside welfare loops. Even as they hope to migrate for better economic returns, the inability to access their welfare dues outside their state of origin renders them reluctant to migrate (Kone et al., 2017). However, migration remains a key driver of economic resurgence, and in order to induce the same, it is important to dismantle administrative and other barriers that inhibit access to welfare programmes across borders. An online migrant database which is updated in real time and perhaps linked to a unique migrant number which can be cross-referenced against Aadhaar might help in this endeavour. Problems with Aadhaar verification notwithstanding, doing so might help in the more targeted dispensation of existing and proposed government benefits such as the 'Migrant Workers Welfare Fund', implementing the 'One Nation, One Ration Card' system, and enrolling migrant workers under the Ayushman Bharat scheme as well as in the potential expansion of the newly launched Garib Kalyan Rojgar Abhiyan which currently focuses only on 116 districts of the country.

The inequalities facing migrants during COVID-19 cannot be addressed without rectifying existing migrant concerns, none more so than their political disenfranchisement (Rajan et al., 2019). It is a sad reality that migrants remain an ignored category because state governments do not see themselves gaining from addressing migrant concerns. Currently political rights, namely that to vote, remain tied to permanent residences, depriving migrants off the ability to politically participate in the state they currently reside in. Granting migrants political visibility would help make their concerns take centre stage during elections. That said, the portability of political rights and particularly its ties to social welfare, is a controversial one; migrant communities are usually excluded from mainstream societies in the states they reside in, and often viewed with suspicion; therefore, enabling political franchise could also lead to parochialism. Nevertheless, political franchise remains a key enabler to migrant welfare, so states should commit to it (Aggarwal, 2019). 
Migrant concerns are unique, yet they cannot be seen in isolation of other concerns plaguing the Indian economy right now. COVID-19 has not created the migrant crisis but merely made its faultlines visible. With the pandemic likely to stretch on indefinitely, future migration patterns remain uncertain, likely to intercept with reverse migration and remigration, both. What is certain, however, is the need for a paradigm shift from the piecemeal way migrant worker issues have been framed thus far. Instead, it is apparent that the crisis requires not a stop-gap arrangement but a humane, dignified, and long-term solution to address migrant needs.

\section{$* * *$}

Acknowledgements: The authors acknowledge the research contribution provided by Ms. Meghna Jayasankar. This chapter is part of a larger status paper titled 'Impact of COVID-19 on Internal Migrants in India' prepared for the UNICEF and published by Rajiv Gandhi National Institute of Youth Development, Sriperumbudur, Tamil Nadu.

\section{References}

Aajeevika, Bureau, 2014. Retrieved from http://www.aajeevika.org/labour-and -migration.php. Accessed on 27 August 2020, 12 October 2020.

Aggarwal, Varun, 2019. 'Missing migrant voters in India and why they matter; states with higher rates of migration known to have lower voter turnouts', FirstPost. Retrieved from https://www.firstpost.com/india/missing-migrant-voters-in-in dia-and-why-they-matter-states-with-higher-rates-of-migration-known-to-have -lower-voter-turnouts-6450361.html. Accessed on 12 October 2020.

Anonymous, 2020. 'Addressing the impacts of the covid-19 pandemic on women migrant workers', Retrieved from https:/www.unwomen.org/-/media/headquar ters/attachments/sections/library/publications/2020/guidance-note-impacts-of -the-covid-19-pandemic-on-women-migrant-workers-en.pdf?la=en\&vs=227. Accessed on 12 October 2020.

Bisoee, Animesh, 2020. 'Sakhis key to migrant database drive', The Telegraph. Retreived from https://www.telegraphindia.com/india/coronavirus-lockdown -sakhis-key-to-migrant-database-drive/cid/1777714. Accessed on 12 October 2020.

Coronavirus in India, 2020. 'COVID-19 lockdown may cost the economy Rs 8.76 lakh crore; here's how', Business Today. Retrieved from https://www.business today.in/opinion/columns/coronavirus-in-india-covid-19-india-lockdown-econo my-cost-gdp-gva-nationwide-shutdown/story/399477.html. Accessed on 12 October 2020.

Dastidar, G. Avishek, 2020. 'Most Shramik trains: Gujarat, Maharashtra to UP and Bihar', The Indian Express. Retrieved from https://indianexpress.com/arti cle/india/most-shramik-trains-gujarat-maharashtra-to-up-and-bihar-6432299/. Accessed on 12 October 2020. 
De, Supriyo, 2019. Internal Migration in India Grows, But Inter-State Movements Remain Low. Retrieved from https://blogs.worldbank.org/peoplemove/intern al-migration-india-grows-inter-state-movements-remain-low. Accessed on 12 October 2020.

Deshingkar, Priya, 2006. 'Internal migration, poverty and development in Asia', ODI Briefing Paper 11. London: Overseas Development Institute.

Government of India, 2017. Report of the Working Group on Migration. Ministry of Housing and Urban Poverty Alleviation.

Iyer, Kavitha, 2020. 'Falling through the holes of Atmanirbhar Bharat schemes, migrant workers seek to return to cities', The Scroll. Retrieved from https://sc roll.in/article/969880/falling-through-the-holes-of-atmanirbhar-bharat-schemes -migrant-workers-seek-to-return-to-cities. Accessed on 12 October 2020.

Jha, Somesh, 2020. 'Ensure that changes to Indian labour laws adhere to global standards', Wire. Retrieved from https://thewire.in/labour/ilo-india-labour-lawscovid-19. Accessed on 12 October 2020.

Kone, Zovanga L., Maggie Y. Liu, and Aaditya Mattoo, Caglar Ozden and Siddarth Sharma, 2017. 'Internal borders and migration in India', World Bank Policy Research Working Paper Series 8244. Washington.

Mahler, Daniel G., Christopher Lakner, R.A.C. Aguilar, and Haoyu Wu, 2020. Updated Estimates of the Impact of COVID-19 on Global Poverty. Retrieved from https://blogs.worldbank.org/opendata/updated-estimates-impact-covid-19 -global-poverty?cid=SHR_BlogSiteShare_EN_EXT. Accessed on 12 October 2020.

Migration Data Portal, 2019. Migration \& Development: Sustainable Development Goals. Retrieved from https://migrationdataportal.org/resource/migration-deve lopment-and-evaluation-where-we-stand-today-and-why. Accessed on 30 August 2020, 12 October 2020.

Ministry of Home Affairs, 2020. National Migrant Information System (NMIS). Retrieved from https://pib.gov.in/PressReleasePage.aspx?PRID=1624540. Accessed on 12 October 2020.

Ministry of Labour, 2019. The Code on Social Security, 2019. Government of India. Ministry of Statistics \& Programme Implementation, 2019. Periodic Labour Force Survey 2017-8. Retrieved from http://www.mospi.gov.in/sites/default/files/p ublication_reports/Annual\%20Report\%2C\%20PLFS\%202017-18_31052019.p df. Accessed on 12 October 2020.

Mitra, Annapurna, 2020. COVID19: A Wake-Up Call for Urban Social Protection in India. Observer Research Foundation. Retrieved from https://www.orfonline.org /expert-speak/covid19-wake-up-call-urban-social-protection-india-63545/\#_ft n6. Accessed on 12 October 2020.

Mitra, Ritwika, 2020. 'Centre to come up with database of tribal migrant workers for livelihood generation amid pandemic', The New Indian Express. Retrieved from https:/www.newindianexpress.com/nation/2020/jul/09/centre-to-come -up-with-database-of-tribal-migrant-workers-for-livelihood-generation-amid -pandemic-2167473.html. Accessed on 12 October 2020.

Mitra, Rohini, Aarohi Damle and Geetika Varshney, 2020. 'Exclusionary policies push migrants to cities' peripheries', IndiaSpend. Retrieved from https://www 
.indiaspend.com/exclusionary-policies-push-migrants-to-cities-peripheries/. Accessed on 12 October 2020.

Nandi, Subhalakshmi, 2017. 'Expert's take: Making unpaid work visible creates livelihoods for rural women', Women. Retrieved from http:/www.unwomen.org /en/news/stories/2017/3/experts-take-subhalakshmi-nandi-unpaid-work\#notes. Accessed on 12 October 2020.

Narayana, D., C.S. Venkiteswaran and M.P. Joseph, 2013. Domestic Migration Labour in Kerala. Government of Kerala.

Nayyar, Gaurav and Kyoung Yang Kim, 2018. 'India's internal labor migration paradox: The statistical and the real', World Bank Policy Research Working Paper 8356. Washington.

Patel, Champa, 2020. COVID-19: The Hidden Majority in India's Migration Crisis. Chatham House. Retrieved from https://www.chathamhouse.org/expert/comment /covid-19-hidden-majority-indias-migration-crisis. Accessed on 12 October 2020.

Prabhu, Nagesh, 2020. 'Pandemic will deepen job and livelihood crisis of migrants: Study', The Hindu. Retrieved from https:/www.thehindu.com/news/national/k arnataka/pandemic-will-deepen-job-and-livelihood-crisis-of-migrants-study/a rticle31439073.ece. Accessed on 12 October 2020.

Press Information Bureau India, 2020. Union Finance Minister Nirmala Sitharaman Addresses a Press Conference. Retrieved from https://www.youtube.com/watch? $\mathrm{v}=\mathrm{hIRebLyGb10.} \mathrm{Accessed} \mathrm{on} 12$ October 2020.

Rajan, S.I., 2013. 'Internal migration and youth in India: Main features, trends and emerging challenges', Discussion Paper, UNESCO, Delhi.

Rajan, S.I., 2020. 'Kerala's experience with COVID-19: What lessons to learn?', SocDem Asia Quarterly, 9(2), 18-22.

Rajan, S.I. and B.D Sami, 2020. 'The way forward on migrant issues', Frontline, 22 May.

Rajan, S.I. and P. Sivakumar, 2018. 'Introduction', in S.I. Rajan and P. Sivakumar (Eds.), Youth Migration in Emerging India: Trends, Challenges and Opportunities. Delhi: Orient BlackSwan, 1-31.

Rajan, S.I. and M. Sumeetha, 2019. Handbook on Internal Migration in India. Delhi: SAGE.

Rajan, S.I. and K.C. Zachariah, 2019. 'Emigration and remittances: New evidence from the Kerala Migration Survey 2018', Centre for Development Studies (CDS) Working Paper. 483. Thiruvananthapuram.

Rajan, S.I, Ashwin Kumar and Arokkiaraj Heller, 2019. 'The realities of voting in India: Perspective from internal labour migrants', Economic and Political Weekly, LIV(18), 12-14.

Rajan, S.I., P Sivakumar and Aditya Srinivasan, 2020. 'The COVID-19 pandemic and internal labour migration in India: A "Crisis of Mobility", Indian Journal of Labour Economics, 63(4).

Ray, S.S., 2020. 'House panel for expansion of EPF/ESIC net for migrant workers', Financial Express. Retrieved from https://www.financialexpress.com/money /house-panel-for-expansion-of-epf-esic-net-for-migrant-workers/2015241/. Accessed on 12 October 2020. 
Rukmini, S., 2020. 'How covid-19 locked out women from job', Livemint. Retrieved from https://www.livemint.com/news/india/how-covid-19-locked-out-women -from-jobs-11591772350206.html. Accessed on 12 October 2020.

Sapra, Ipsita, 2020. 'Why don't we see the women? The untold story of COVID-

19 migration', Indian Express. Retrieved from https://indianexpress.com/article /opinion/why-dont-we-see-the-women-the-untold-story-of-covid-19-migration $-6378557 /$. Accessed on 12 October 2020.

Sharan, V P., 2020. 'Jharkhand survey maps skill-sets and find most migrant workers outside central schemes', The National Herald. Retrieved from https:/www.nat ionalheraldindia.com/india/jharkhand-survey-maps-skill-sets-and-find-most-m igrant-workers-outside-central-schemes. Accessed on 12 October 2020.

Sharma, N.A. and D. Arora, 2011. Social Protection in India: Issues and Challenges, Delhi: Institute for Human Development.

Sharma, Palak, 2020. 'Corona and the tragic dynamics of labour economics in India', The Leaflet. Retrieved from https://theleaflet.in/corona-and-the-tragic-d ynamics-of-labour-economics-in-india/. Accessed on 12 October 2020.

Simran, Rohini et al., 2019. 'India's social security code, 2019', The Medium. Retrieved from https:/medium.com/@indiamigration/indias-social-security-co de-2019-4fe5be609faf. Accessed on 12 October 2020.

Srivastava, P., 2020. 'Yogi govt completes skill-mapping of 23.5 lakh migrant workers, 18 lakh want jobs in UP', Print. Retrieved from https://heprint.in/ india/yogi-govt-completes-skill-mapping-of-23-5-lakh-migrant-workers-18-lak h-want-jobs-in-up/435450/. Accessed on 12 October 2020.

Srivastava, R., 2013. A Social Protection Floor for India, India: International Labour Organization.

Stranded Workers Action Network, 2020. 32 Days and Counting: COVID-19 Lockdown, Migrant Workers, and the Inadequacy of Welfare Measures in India. Retrieved from https://covid19socialsecurity.files.wordpress.com/2020/05/32 -days-and-counting_swan.pdf. Accessed on 12 October 2020.

The Week, 2020. Kerala Sets An Example for Rest of India with Its Exceptional Treatment of 'Guest Workers'. Retrieved from https:/www.theweek.in/news/ india/2020/04/20/kerala-sets-an-example-for-rest-of-india-with-its-exceptional -treatment-of-guest-workers.html. Accessed on 12 October 2020.

Tumbe, Chinmoy. 2018. India Moving: A History of Migration. Delhi: Penguin.

United Nations Development Programme and Oxford Poverty and Human Development Initiative. 2020. Charting Pathways out of Multidimensional Poverty: Achieving the SDGs. New York: United Nations.

Venugopal, Vasudha and Vatsala Gaur, 2020. '3 states finalising databases for benefit of migrant workers', The Economic Times. Retrieved from https://ec onomictimes.indiatimes.com/news/politics-and-nation/3-states-finalising-dat abases-for-benefit-of-migrant-workers/articleshow $/ 75983331$.cms? from=mdr. Accessed on 12 October 2020.

World Bank, 2020a. 'Employment in services, female (\% of female employment) (modeled ILO estimate)'. Retrieved from https://data.worldbank.org/indicator/ SL.SRV.EMPL.FE.ZS?contextual=female-employment-by-sector\&view=chart. Accessed on 12 October 2020. 


\section{Rajan, Rajagopalan, and Sivakumar}

World Bank, 2020b. 'Migration and development brief 32. COVID-19 crisis through a migration lens', Migration and Development Brief 32. Washington.

Yadav, Sidharth, 2020. 'Madhya Pradesh launches 'RozgarSetu' scheme for skilled workers', The Hindu. Retrieved from https://www.thehindu.com/news/national/ other-states/madhya-pradesh-launches-rozgar-setu-scheme-for-skilled-workers/ article31701696.ece. Accessed on 12 October 2020.

Zachariah, K.C, E T Mathew and S Irudaya Rajan, 1999. 'Impact of migration on Kerala economy', CDS Working Paper. 297. Thiruvananthapuram.

Zachariah, K.C, E T Mathew and S Irudaya Rajan, 2000. 'Socio-economic and demographic consequences of migration in Kerala', CDS Working Paper. 303. Thiruvananthapuram. 